\title{
DIGITAL SIGNATURE PADA CITRA MENGGUNAKAN RSA DAN VIGENERE CIPHER BERBASIS MD5
}

\author{
Lekso Budi Handoko \\ Fakultas Ilmu Komputer, Program Studi Teknik Informatika \\ Universitas Dian Nuswantoro \\ Email: handoko@dsn.dinus.ac.id \\ Chaerul Umam \\ Fakultas Ilmu Komputer, Program Studi Teknik Informatika \\ Universitas Dian Nuswantoro \\ Email: chaerul@dsn.dinus.ac.id \\ De Rosal Ignatius Moses Setiadi \\ Fakultas Ilmu Komputer, Program Studi Teknik Informatika \\ Universitas Dian Nuswantoro \\ Email: moses@dsn.dinus.ac.id \\ Eko Hari Rachmawanto \\ Fakultas Ilmu Komputer, Program Studi Teknik Informatika \\ Universitas Dian Nuswantoro \\ Email: eko.hari@dsn.dinus.ac.id
}

\begin{abstract}
ABSTRAK
Salah satu teknik yang populer untuk mengamankan data dengan tingkat keamanan yang tinggi yaitu kriptografi. Berbagai penelitian telah dilakukan dengan menggabungkan kunci simteris dan kunci asimteris untuk mendapatkan keamanan ganda. Dalam makalah ini, tanda tangan digital diterapkan melalui Rivest Shamir Adleman (RSA) sebagai algoritma kunci asimteris yang akan digabung dengan algoritma kunci simteris Vigenere Cipher. RSA yang tahan terhadap serangan karena menggunakan proses eksponensial dan kuadrat besar dapat menutupi kelemahan Vigenere Cipher, sedangkan Vigenere Cipher dapat mencegah kemunculan huruf yang sama dalam cipher yang mempunyai pola tertentu. Vigenere cipher mudah diimplementasikan dan menggunakan operasi substitusi. Untuk mengkompresi nilai numerik yang dihasilkan secara acak, digunakan fungsi hash yaitu Message Digest 5 (MD5). percobaan dalam makalah ini telah memberikan kontribusi dalam peningkatan kualitas enkripsi dimana citra digital dioperasikan dengan MD5 yang kemudian hasilnya akan diubah menjadi RSA. Fungsi hash awal yaitu 32 karakter diubah menjadi 16 karakter yang akan menjadi inputan untuk proses RSA dan Vigenere Cipher. Pada citra berwarna yang digunakan sebagai media operasi, akan dilakukan pengecekan apakah citra tersebut sudah melalui proses digital signature.
\end{abstract}

Kata kunci: digital signature; rivest shamir adleman (RSA); vigenere cipher; message digest 5 (MD5).

\begin{abstract}
One of the most popular techniques for securing data with high security is cryptography. Various studies have been done by combining simteric keys and asymmetric keys to obtain double security. In this paper, digital signatures are applied via Rivest Shamir Adleman (RSA) as an asymmetric key algorithm to be combined with Vigenere Cipher's simultant key algorithm. RSA is resistant to attack because it uses exponential process dan big square to cover the weakness of Vigenere Cipher, while Vigenere Cipher can prevent the occurrence of the same letter in a cipher that has a certain pattern. Vigenere ciphers are easy to implement and use substitution operations. To compress randomly generated numerical values, a hash function is Message Digest 5 (MD5). the experiments in this paper have contributed to the enhancement of the quality of the encryption in which the digital image is operated with MD5 which will then be converted to RSA. The initial 32-character hash function is converted to 16 characters which will be input for RSA and Vigenere Cipher processes. In the color image used as a media container, will be checked whether the image has been through the process of digital signature.
\end{abstract}

Keywords: digital signature; rivest shamir adleman (RSA); vigenere cipher; message digest 5 (MD5). 


\section{PENDAHULUAN}

Kriptografi menjadi populer dan sering digunakan dalam menyelesaikan permasalahan dalam kehidupan manusia menggunakan algroitma tertentu misalnya Vernam Cipher, One Time Pad (OTP) [1], Advance Encryption Standard (AES) [2]. Beberapa algoritma tersebut juga dapat dikombinasikan dengan teknik watermarking atau steganografi untuk mendapatkan keamanan ganda. Salah satu model impelementasi kriptografi yang hingga saat ini masih digunakan, khususnya dalam mengamankan data dalam jaringan komputer yaitu digital signature [3]. Digital signature merupakan bentuk komputasional dari tanda tangan digital konvensional dimana byte-byte pada citra digital akan di cek dengan tujuan otentikasi data. Otentikasi data menjadi salah satu tujuan utama dilakukannya proses kriptografi. Menurut Saha [4], tujuan utama kriptografi dapat dibagi menjadi 5 macam yaitu: (1) Otentikasi data, (2) kerahasiaan data, (3) non-repudiasi, (4) integritas data, (5) ketersediaan data. Dalam makalah ini akan dibahas mengenai implementasi teknik kriptografi dalam melakukan proses otentikasi data melalui digital signature.

Otentikasi data merupakan proses identifikasi atau pengenalan terhadap data yang dikirimkan dari satu pihak ke pihak lain. Untuk mengamankan data, maka perlu adanya tanda tangan digital [5]. Dalam digital signature dapat diilustraiskan apabila seseorang mengubah dokumen orang lain dan berpura-pura menjadi pemilik dokumen tersebut, maka manupulasi data dapat saja terjadi. Orang lain yang bukan pemilik dokumen dapat menyalin tanda tangan seseorang dalam dokumen mereka sendiri secara ilegal, tetapi dalam digital signature penyusup maupun orang awam tidak dapat melakukan manipulasi pada dokumen tersebut karena dokumen telah ter-otentikasi sebagai milik sah dari pemilik asli dokumen tersebut [6]. Informasi tersebut dapat diotentikasi keasliannya, isi data maupun waktu pengirimannya. Proses otentikasi data, fungsi hash sering digunakan sebagai alat untuk menyimpan dan memproses message integrity. Beberapa bentuk fungsi hash yang dapat digunakan misalnya MD4, MD5, SHA-1, SHA-256, atau SHA-512. Bentuk dan konsep fungsi hash lebih detail akan dijelaskan pada sub bab berikutnya. Fungsi hash mempunyai dua bagian operasi yaitu padding dan kompresi.

\section{METODOLOGI PENELITIAN}

\subsection{Secure Hash Function (SHA)}

Otentikasi pesan adalah layanan yang digunakan untuk memverifikasi integritas pesan. Otentikasi pesan memastikan bahwa data yang diterima sama persis dengan yang dikirim. Fungsi hash digunakan untuk menyediakan otentikasi pesan [7]. Nilai kode hash juga disebut sebagai pesan Digest. Nilai fungsi hash digunakan untuk otentikasi pesan dalam hal ini: "Pengirim menghitung nilai kode hash sebagai fungsi bit dalam pesan dan mentransfer baik nilai hash dan pesan di sisi penerima. Menurut Ganeshkumar [8] tanda tangan digital digunakan untuk memilih informasi yang tepat dan konten resmi yang dienkripsi dengan kunci pribadi pengirim yang hanya diketahui oleh pengirim. Pada sisi penerima nilai hash dihitung untuk bit pesan dan kemudian nilai hash yang dihasilkan dibandingkan dengan nilai hash yang masuk. Oleh karena itu, tanda tangan yang valid memverifikasi bahwa pesan itu dibuat oleh pengirim. Kunci publik yang terkait digunakan untuk memverifikasi tanda tangan. Jika tanda tangan valid, maka pesan diotentikasi.

Sesuai perkembangannya, bentuk fungsi hash dari Message Digest telah berkemabang menjadi Secure Hash Algorithm (SHA) antara lain:

Tabel 1. Macam Secure Hash Function (SHA)

\begin{tabular}{|c|c|c|c|c|c|c|c|c|}
\hline \multicolumn{2}{|c|}{ Nama Algoritma } & $\begin{array}{c}\text { Output } \\
\text { size (bit) }\end{array}$ & $\begin{array}{l}\text { Internal } \\
\text { State size }\end{array}$ & $\begin{array}{c}\text { Block } \\
\text { size }\end{array}$ & $\begin{array}{l}\text { Maksimum } \\
\text { pesan (bit) }\end{array}$ & $\begin{array}{c}\text { Jumlah } \\
\text { Iterasi }\end{array}$ & Operasi & $\begin{array}{c}\text { Security } \\
\text { bit }\end{array}$ \\
\hline \multirow{2}{*}{\multicolumn{2}{|c|}{ MD5 }} & 128 & 128 & 512 & $\begin{array}{c}\text { Tidak } \\
\text { terbatas }\end{array}$ & 64 & $\begin{array}{c}\text { And, xor, } \\
\text { rot, add } \\
\left(\bmod 2^{32}\right), \\
\text { or }\end{array}$ & $<64$ \\
\hline & & 160 & 160 & 512 & $2^{64}-1$ & 80 & & $\begin{array}{l}<34 \\
<63\end{array}$ \\
\hline \multirow[t]{2}{*}{$\begin{array}{l}\text { SHA } \\
2\end{array}$} & SHA 224 & 224 & 256 & 512 & $2^{64}-1$ & 64 & $\begin{array}{c}\text { And, xor, } \\
\text { rot, add } \\
\left(\bmod 2^{32}\right), \\
\text { or, shr }\end{array}$ & 112 \\
\hline & $\begin{array}{l}\text { SHA } 256 \\
\text { SHA } 384\end{array}$ & $\begin{array}{l}256 \\
382\end{array}$ & $\begin{array}{l}256 \\
512\end{array}$ & $\begin{array}{l}512 \\
1024\end{array}$ & $\begin{array}{l}2^{64}-1 \\
2^{128}-1\end{array}$ & $\begin{array}{l}64 \\
80\end{array}$ & $\begin{array}{r}\text { And, xor, } \\
\text { rot, add }\end{array}$ & $\begin{array}{l}128 \\
192\end{array}$ \\
\hline
\end{tabular}




\begin{tabular}{|c|c|c|c|c|c|c|c|c|}
\hline \multicolumn{2}{|c|}{ Nama Algoritma } & $\begin{array}{c}\text { Output } \\
\text { size (bit) }\end{array}$ & $\begin{array}{l}\text { Internal } \\
\text { State size }\end{array}$ & $\begin{array}{l}\text { Block } \\
\text { size }\end{array}$ & \multirow[t]{2}{*}{$\begin{array}{c}\text { Maksimum } \\
\text { pesan (bit) }\end{array}$} & $\begin{array}{l}\text { Jumlah } \\
\text { Iterasi }\end{array}$ & \multirow{2}{*}{$\frac{\text { Operasi }}{\left(\bmod 2^{64}\right)}$} & $\begin{array}{c}\text { Security } \\
\text { bit }\end{array}$ \\
\hline & SHA 512 & 512 & & & & & & 256 \\
\hline & SHA & 224 & & & & & or, shr & 288 \\
\hline & $512 / 224$ & 224 & & & & & & 288 \\
\hline & SHA & 256 & & & & & & 256 \\
\hline & $512 / 256$ & & & & & & & \\
\hline & SHA3-224 & 224 & & 1152 & Tidak & 24 & & 448 \\
\hline & SHA3-256 & 256 & & 1088 & & & & 512 \\
\hline SHA & SHA3-384 & 384 & 1600 & 832 & & & And, xor, & 768 \\
\hline & SHA3-512 & 512 & & 576 & & & rot, not & 1024 \\
\hline & SHAKE 128 & berubah- & & 1344 & & & & 256 \\
\hline & SHAKE 256 & ubah & & 1088 & & & & 512 \\
\hline
\end{tabular}

Pada Tabel 1, diketahui bahwa algoritma hash adalah keluarga fungsi hash kriptografi yang diterbitkan oleh National Institute of Standards and Technology (NIST) sebagai U.S. Federal Information Processing Standard (FIPS), yaitu:

a) SHA-0: Sebuah retronym diterapkan pada versi asli dari fungsi hash 160-bit yang diterbitkan pada tahun 1993 dengan nama "SHA". Itu ditarik segera setelah publikasi karena "cacat signifikan" yang tidak diungkapkan dan digantikan oleh versi SHA-1 yang sedikit direvisi.

b) SHA-1: Fungsi hash 160-bit yang menyerupai algoritma MD5 sebelumnya. Ini dirancang oleh National Security Agency (NSA) untuk menjadi bagian dari Digital Signature Algorithm. Kelemahan kriptografi ditemukan dalam SHA-1, dan standar itu tidak lagi disetujui untuk sebagian besar penggunaan kriptografi setelah 2010.

c) SHA-2: Keluarga dengan dua fungsi hash yang sama, dengan ukuran blok yang berbeda, yang dikenal sebagai SHA-256 dan SHA-512. Mereka berbeda dalam ukuran kata; SHA-256 menggunakan kata-kata 32-bit di mana SHA-512 menggunakan kata-kata 64-bit. Ada juga versi terpotong dari setiap standar, yang dikenal sebagai SHA-224, SHA-384, SHA-512/224 dan SHA512/256. Ini juga dirancang oleh NSA.

d) SHA-3: Fungsi hash yang sebelumnya disebut Keccak, dipilih pada tahun 2012 setelah kompetisi publik di antara desainer non-NSA. Ini mendukung panjang hash yang sama dengan SHA-2, dan struktur internalnya berbeda secara signifikan dari sisa keluarga SHA.

\subsection{Message Digest 5 (MD5)}

Algoritma MD5 dikembangkan oleh Profesor Ronald L. Rivest pada tahun 1991. Dalam algoritma ini, pesan panjang secara langsung diambil sebagai input dan menghasilkan output sebagai 128-bit "sidik jari" atau "pesan digest" dari input [9]. Algoritma MD5 ditujukan untuk aplikasi tanda tangan digital, di mana sebelum dienkripsi dengan kunci privat di bawah cryptosystem publickey seperti RSA, file besar harus dikompresi dengan cara yang aman. MD5 adalah fungsi hash paling populer yang menghasilkan 128-nilai hash bit atau 16 karakter [10]. MD5 umumnya digunakan untuk memeriksa integritas file. Operasi pergeseran siklus, penambahan modular dan operasi boolean bitwise. Menurut Ardy [11], berikut merupakan operasi pada Message Digest:

a) Padding

1) Langkah 1: Pesan ditambahkan dengan sejumlah bit padding hingga kongruen dengan 448 modulo 512 .

2) Langkah 2: Jika panjang pesan adalah 448 bit, maka pesannya ditambahkan dengan 512 bit hingga 960 bit. Dengan demikian, panjang bit padding adalah antara 1 dan 512.

3) Langkah 3: Padding bit terdiri dari bit "1" diikuti oleh sisa "0" bit.

4) Langkah 4: Pesan yang telah diberi bit padding kemudian ditambahkan lagi dengan 64-bit yang menyatakan panjang pesan asli.

5) Langkah 5: Jika panjang pesan lebih besar dari 264 kemudian panjang akan digunakan dalam modulo 264. Dengan kata lain, jika panjang pesan awal adalah K bit, maka 64 bit menambahkan $\mathrm{K}$ modulo 264. Setelah ditambahkan dengan 64 bit, panjang pesan sekarang menjadi kelipatan 512 bit.

b) Kompresi

1) Langkah 1: MD5 membutuhkan 4 buffer setiap 32 bit. Jumlah seluruhnya panjang buffer adalah 4 x 32 bit $=128$ bit. Keempat buffer ini mengakomodasi hasil tengah dan akhir. Keempat buffer ini diberi nama A, B, C, dan D. Setiap buffer diinisialisasi dengan nilai: 
2) huruf A: 012345 67; huruf B: 89 AB CD EF; huruf C: FE DC BA 98; huruf D: 76543210. Register ini biasanya disebut variabel rantai.

3) Langkah 2: Pesan dibagi menjadi blok L yang panjangnya 512-bit setiap blok menggunakan fungsi nonlinier.

\subsection{Vigenere Cipher}

Vigenere cipher ditemukan oleh Giovan Battista Bellaso pada tahun 1553 dan dikembangkan oleh Blaisede Vigenere karena menemukan kunci yang lebih aman yaitu autokey cipher [12]. Vigenere cipher menggunakan bujur sangkar vigenere yang diperoleh dari perhitungan Caesar Cipher sesuai Persamaan (1) sampai Persamaan (3).

$C_{i}=\left(P_{i}+K_{i}\right) \bmod 26$

$C i=(p i+k i) \bmod n($ untuk vigenere dengan jumlah karakter $n)$

$\left.P_{i}=C_{i}-K_{i}\right) \bmod 26$

Dimana $m$ adalah panjang kunci, $i=1,2,3, \ldots$, (panjang kunci) dan $j=((i-1) \bmod 25)+1$. Menurut Kromodimeoldjo [13], Vigenere cipher adalah salah satu algoritma kriptografi yang sederhana. Contoh perhitungan dengan menggunakan Tabula Recta dapat diilustrasikan sesuai Gambar 1, sedangkan Gambar 2 adalah tabula recta Vigenere.
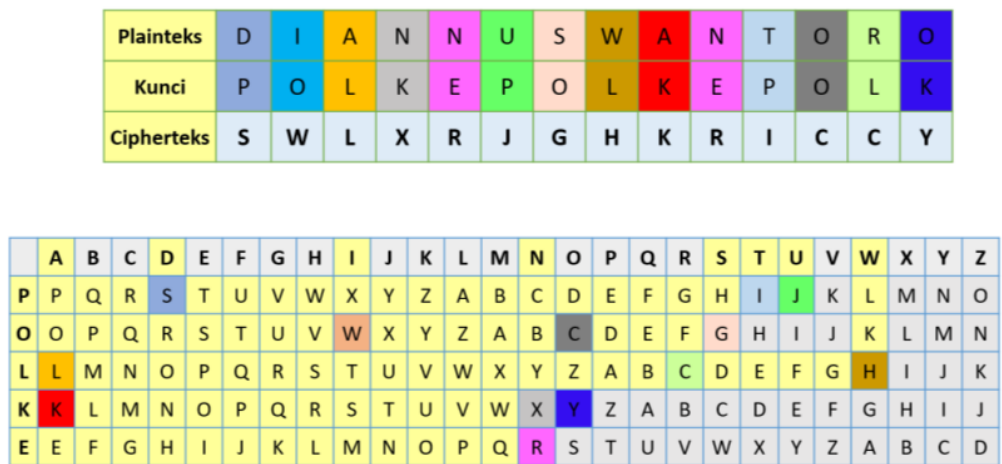

Gambar 1. Contoh Enkripsi dengan Tabula Recta pada Vigenere Cipher

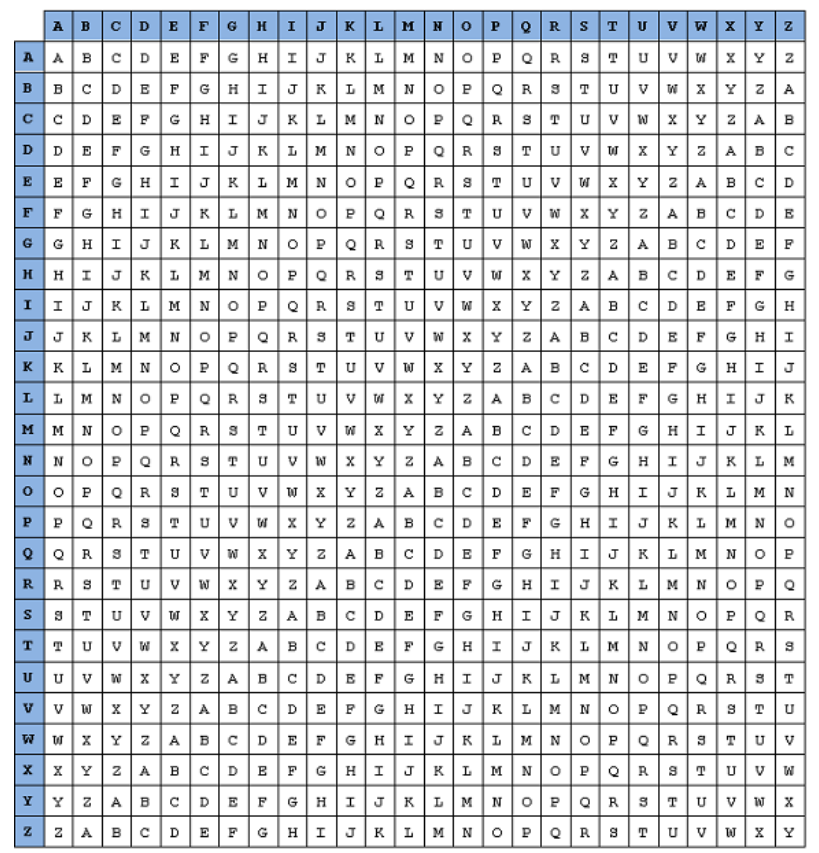

Gambar 2. Tabula Rectra Vigenere Cipher 


\subsection{Rivest Shamir Adleman (RSA)}

RSA adalah algoritma kriptografi asimetris yang merupakan algoritma pertama yang paling tepat untuk penandatanganan dan enkripsi dan salah satu penemuan kriptografi utama pertama dengan kunci publik [11]. Dalam metode ini, ada tiga bagian utama: pembuatan kunci, enkripsi, dan proses dekripsi [14]. Dalam algoritma RSA, diperlukan proses enkripsi dan dekripsi kunci publik dan kunci privat. Berikut adalah langkah-langkah untuk menghasilkan kunci publik dan pribadi pada algoritma RSA [15], [16]:

a) Generalisasi Kunci

Langkah 1: Hasilkan dua bilangan prima $p$ dan $q$, di mana $p \neq q$.

Langkah 2: Hitung $p$ dan $q$ menggunakan Persamaan 4 sampai Persamaan 6:

$$
\begin{aligned}
& n=p \times q \\
& \emptyset(n)=(p-1) \times(q-1) \\
& k=\emptyset(n)+1
\end{aligned}
$$

Langkah 3: Fokuskan nilai $k$ untuk mendapatkan nilai coprime, jadi faktor pertama yang digunakan untuk $e$ dan faktor kedua adalah nilai $d$. Langkah 4: Kunci publik kami adalah $[e, n]$ untuk pengirim dan pasangan kunci privat adalah $[d, n]$ untuk penerima.

b) Enkripsi

Untuk mengenkripsi pesan pengirim $(M)$ menggunakan kunci publik $[e, n]$ yang telah dihasilkan pada proses pembuatan kunci Untuk menghasilkan cipher menggunakan Persamaan 7.

$c=\left(m^{e}\right) \bmod n$

Dimana $c$ adalah elemen dari cipher $(c \in C), m$ adalah elemen dari pesan $(m \in M)$, $e$ adalah kunci publik dan $n$ dapat ditampilkan pada Persamaan 4.

c) Dekripsi

Untuk mendekripsi cipher $(C)$, dari penerima gunakan kunci privat $[d, n]$. Di bawah ini adalah proses dekripsi dapat digunakan Persamaan 8 untuk melakukan proses dekripsi.

$$
m=\left(c^{d}\right) \bmod n
$$

Dimana, $m$ adalah elemen dari pesan $(m \in M), c$ sebagai elemen dari cipher $(c \epsilon C)$, d adalah kunci privat. Sedangkan $n$ diperoleh dari Persamaan 4.

\section{HASIL DAN PEMBAHASAN}

Dalam makalah ini, kami menggunakan model digital signature sesuai [11] yang diilustrasikan pada Gambar 3. 


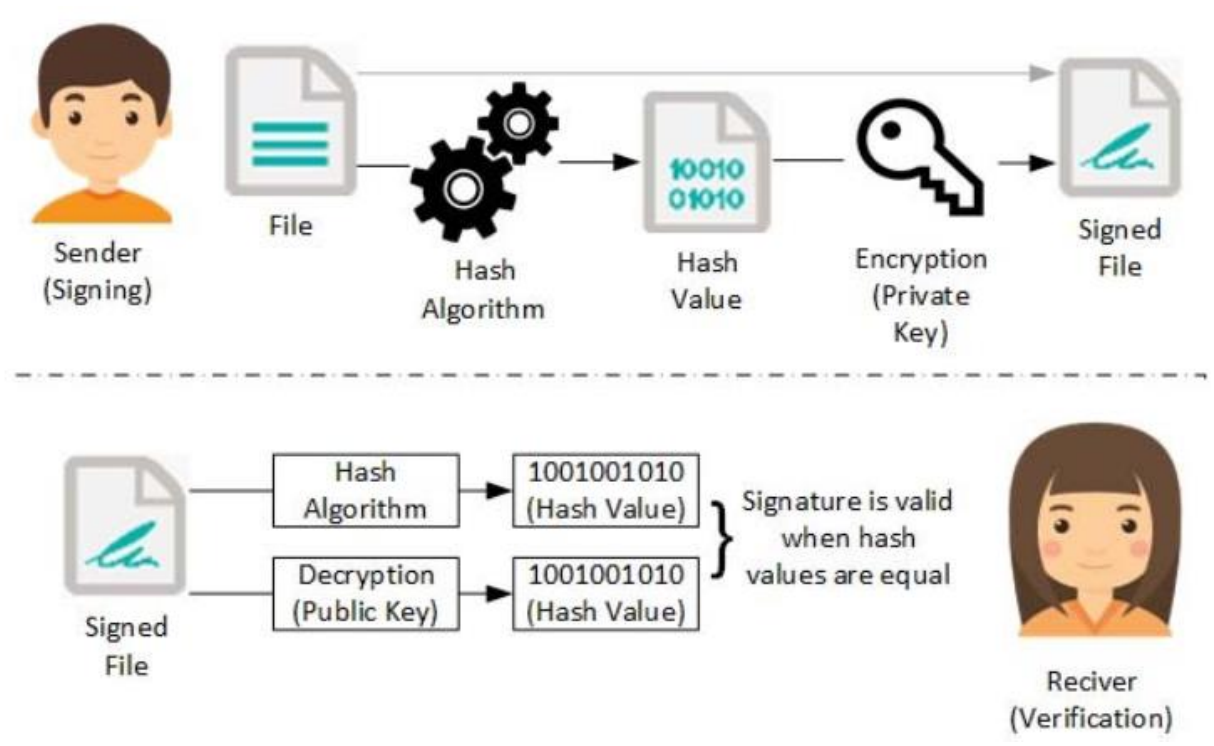

Gambar 3. Model Digital Signature yang Digunakan [11]

Dalam makalah ini, percobaan dilakukan dengan membuat fungsi MD5 terlebih dahulu. Fungsi MD5 dalam digital signature yang kami uji coba yaitu untuk melakukan fungsi hashing pada citra digital. Karakter awal sepanjang 32 karakter kemudian diubah menjadi 16 karakter melalui operasi fungsi hash. Hasil dari 16 karakter tersebut kemudian menjadi inputan dalam proses enkripsi menggunakan RSA dan Vigenere Cipher.

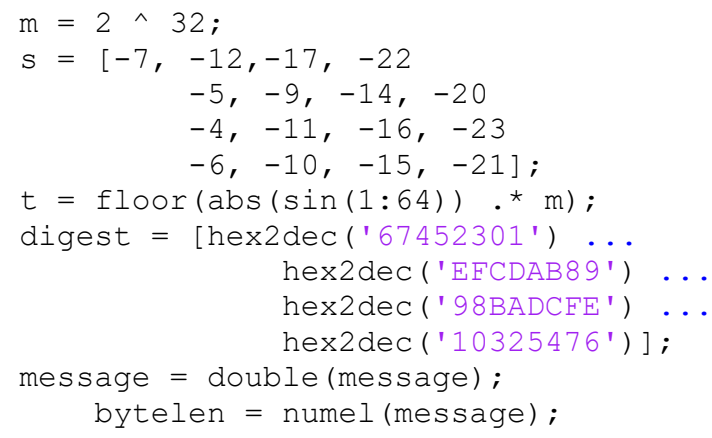

Pada operasi MD5, kami menggunakan tabel cirshift berisi bilangan negatif dikarenakan tabel ini merupakan tabel left shift. Fungsi hex2dec digunakan untuk proses inisialisasi hash menjadi baris vektor dari 32 bit integer. Apabila message yang digunakan mengandung karakter maka lakukan proses perubahan ke nilai ASCII. Berikut ini adalah proses pada setiap blok 512-bit. Hal ini dikarenakan kami menggunakan 32 bit integer, sehingga setiap blok mempunyai 16 elemen dimana jumlah pesan dapat diartikan menjadi message $=\mathrm{k}+(0: 15)$ seperti pada pseudocode berikut.

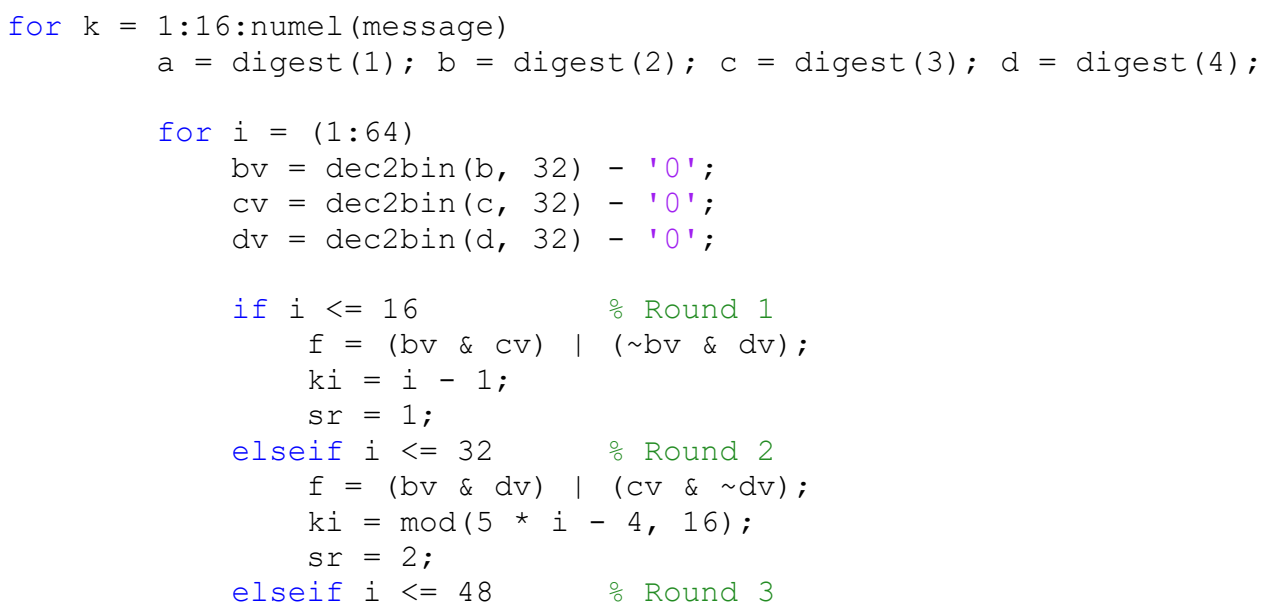




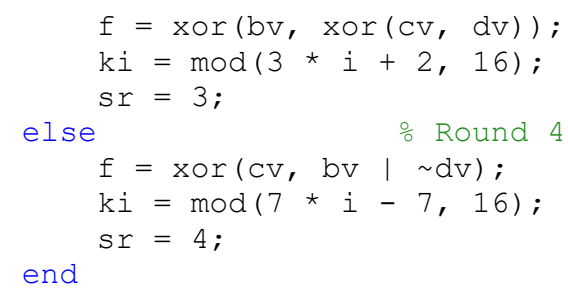

Pada percobaan yang kami lakukan, kunci pada algoritma RSA dikalkulasikan menggunakan nilai $p$ $=7$ dan $q=13$ dimana $n=p^{*} q$ dan teta $=(p-1) *(q-1)$. berikut adalah $p$ seudocode untuk membuat MD5 pada citra. Citra dikonversi dalam bentuk alias $(\mathrm{x}, \mathrm{y}, \mathrm{z})$ menjadi string. Hal ini berlaku bagi proses enkripsi maupun dekripsi.

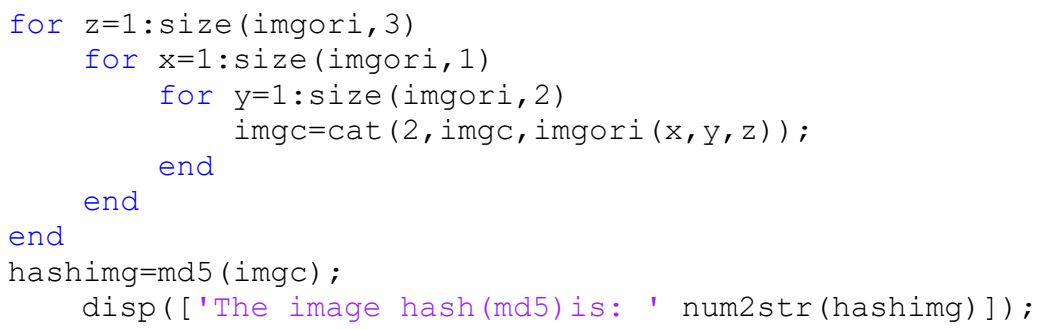

Untuk citra asli kami menggunakan citra berwarna 256x256 piksel dengan format *.bmp, *.tif, dan *.jpg sesuai Gambar 4.

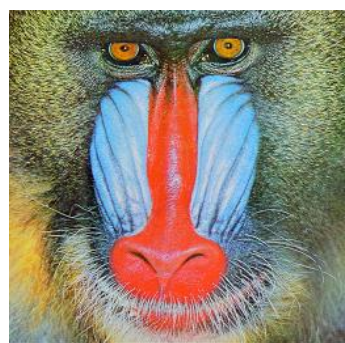

Babbon.bmp

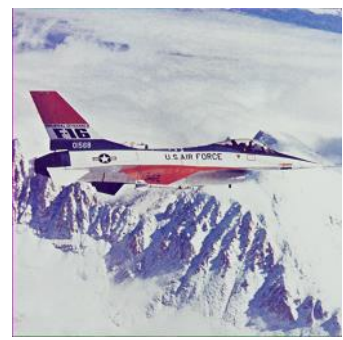

F16.tif

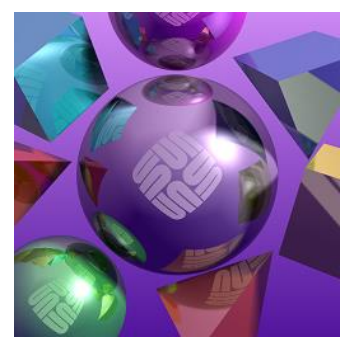

Logo.bmp

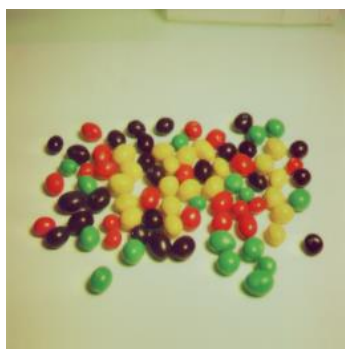

Candy.jpg

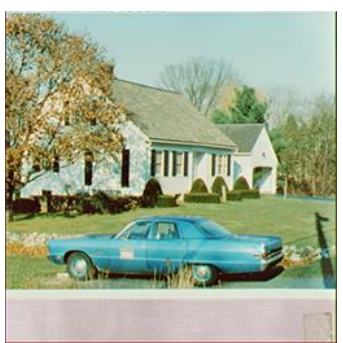

House.jpg

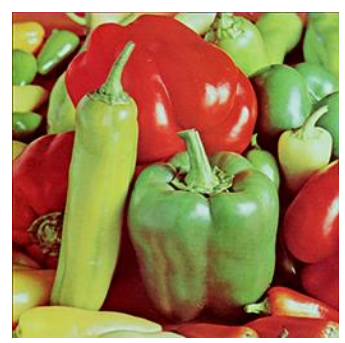

Peppers.jpg

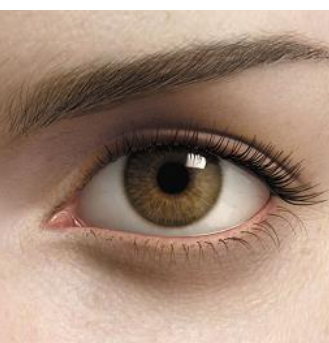

Eye.bmp

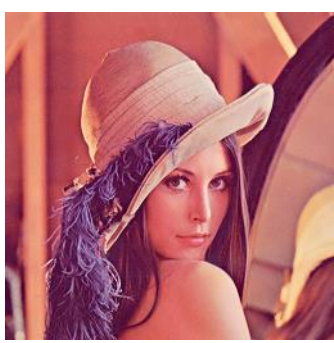

Lena.bmp

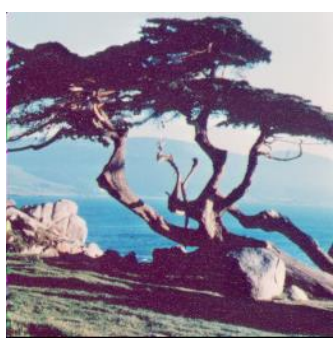

View.jpg

Gambar 4. Citra Asli 
Sedangkan hasil proses otentikasi dengan kunci publik 13,91 dan kunci privat 61,91 dapat dilihat pada Tabel 2 berikut.

Tabel 2. Proses Otentikasi Citra

\begin{tabular}{|c|c|c|c|c|c|}
\hline Citra & Fungsi hash & $\begin{array}{c}\text { Pre-processing } \\
\text { hash } 2 \text { block }\end{array}$ & $\begin{array}{c}\text { Digital } \\
\text { Signature }\end{array}$ & $\begin{array}{c}\text { Citra Yang di } \\
\text { Cek }\end{array}$ & Keterangan \\
\hline & $\begin{array}{c} \\
\text { 48EA134BF167 } \\
\text { EE21CC80EFE } \\
6 D B 98 E A B C\end{array}$ & $\begin{array}{cccc}72 & 234 & 19 & 75 \\
241 & 103 & 238 & 33 \\
204 & 128 & 239 \\
230 & 219 & 152 \\
234 & 188\end{array}$ & $\begin{array}{rrrr}72 & 52 & 19 & 75 \\
59 & 12 & 56 & 33 \\
22 & 37 & 57 & 48 \\
37 & 61 & 52 & 6\end{array}$ & & Signatured \\
\hline & $\begin{array}{c}F E 1994827892 \\
A C F 53 D 82 D C \\
A 2 C 2 A 64 F 0 C\end{array}$ & \begin{tabular}{ccccc}
254 & 25 & 148 & 130 \\
120 & 146 & 172 \\
245 & 61 & 130 & 220 \\
162 & 194 & 166 & 79 \\
4 & \multicolumn{4}{c}{12}
\end{tabular} & $\begin{array}{llll}72 & 25 & 57 & 39 \\
29 & 55 & 81 & 63 \\
61 & 39 & 38 & 71 \\
12 & 75 & 79 & 12\end{array}$ & & Signatured \\
\hline & $\begin{array}{c}F 16775025 E B 9 \\
\text { B347F8F39089 } \\
\text { A4264A6E }\end{array}$ & $\begin{array}{ccccc}241 & 103 & 117 & 2 \\
94 & 185 & 179 & 71 \\
248 & 243 & 144 \\
137 & 164 & 38 & 74 \\
110 & \end{array}$ & $\begin{array}{ccccc}59 & 12 & 26 & 2 & 3 \\
3 & 88 & 71 & 66 & 61 \\
53 & 46 & 73 & 38 \\
74 & 19 & \end{array}$ & & Signatured \\
\hline & $\begin{array}{c}\text { OC83D827644F } \\
9 C B 27 C 5 A D A O \\
D 12 C 19 E D C\end{array}$ & $\begin{array}{rrrr}12 & 131 & 216 & 39 \\
100 & 79 & 156 & 178 \\
124 & 90 & 218 & 13 \\
18 & 193 & 158 & 220\end{array}$ & $\begin{array}{ccccc}12 & 40 & 34 & 39 & 9 \\
79 & 65 & 87 & 33 \\
90 & 36 & 13 & 18 \\
11 & 67 & 38\end{array}$ & & Signatured \\
\hline & $\begin{array}{c}\text { 03A8C03F9C3 } \\
7 B 1002 B 4 E 95 B \\
E C 7 B A D 373\end{array}$ & $\begin{array}{ccccc}3 & 168 & 192 & 63 \\
156 & 55 & 177 & 0 \\
43 & 78 & 149 & 190 \\
199 & 186 & 211 \\
& 115 & \end{array}$ & $\begin{array}{cccccc}3 & 77 & 10 & 63 & 65 \\
55 & 86 & 0 & 43 & 78 \\
58 & 8 & 17 & 4 & 29 \\
& & & 24 & & \\
& & & \end{array}$ & & Signatured \\
\hline & $\begin{array}{l}\text { A43AED63C10 } \\
\text { D809B1E598E } \\
7 A C 3 D E C D 45\end{array}$ & $\begin{array}{cccc}164 & 58 & 237 & 99 \\
193 & 13 & 128 & 155 \\
30 & 89 & 142 & 122 \\
195 & 222 & 205 & 69\end{array}$ & $\begin{array}{cccccc}73 & 58 & 55 & 8 & 11 \\
13 & 37 & 64 & 30 \\
89 & 51 & 31 & 13 \\
40 & 23 & 69\end{array}$ & & Signatured \\
\hline & $\begin{array}{c}4 B 27 D B 9 B F 41 \\
F 3 B F F E 11 C E C \\
9651 F 8 D E 9 A\end{array}$ & $\begin{array}{rrrr}75 & 39 & 219 & 155 \\
244 & 31 & 59 & 255 \\
225 & 28 & 236 & 150 \\
81 & 248 & 222 & 154\end{array}$ & $\begin{array}{llll}75 & 39 & 37 & 64 \\
62 & 31 & 59 & 73 \\
43 & 28 & 54 & 59 \\
81 & 66 & 40 & 63\end{array}$ & & Signatured \\
\hline & $\begin{array}{c}E 6 B 2 E 891 D 79 \\
B E A 5 A A 49 E 7 E \\
28975 F F 8 F 6\end{array}$ & $\begin{array}{rrrrr}230 & 178 & 232 \\
145 & 215 & 155 \\
234 & 90 & 164 & 158 \\
126 & 40 & 151 & 95 \\
248 & 246\end{array}$ & $\begin{array}{cccc}48 & 87 & 50 & 54 \\
33 & 64 & 52 & 90 \\
73 & 67 & 35 & 40 \\
60 & 4 & 66 & 64\end{array}$ & & Signatured \\
\hline & $\begin{array}{c}3 A 0 D D D A 28 E 3 \\
696770 B 78904 \\
6 B E 6748 D 4\end{array}$ & $\begin{array}{cccc}58 & 13 & 221 & 162 \\
142 & 54 & 150 & 119 \\
11 & 120 & 144 & 70 \\
190 & 103 & 72 & 212\end{array}$ & $\begin{array}{rrrrr}58 & 13 & 39 & 71 \\
51 & 54 & 59 & 28 \\
11 & 29 & 53 & 70 & 8 \\
12 & 72 & 30 & \end{array}$ & & Signatured \\
\hline
\end{tabular}

Berdasarkan hasil percobaan yang telah diilustrasikan pada Tabel 2, citra asli diproses untuk mengetahui nilai heksadesimal yang dihasilkan dari proses hashing menggunakan algoritma MD5. selanjutnya akan diperoleh nilai hashing 2 blok dan nilai pada digital signature dengan menginputkan kunci. Pada tahap akhir, citra yang diproses tadi akan disimpan dalam database dan dilakukan proses pengecekan untuk mengetahui apakah digital signature sudah tertanam dalam citra tersebut dan terkenali sebagai data ter-signature. Seluruh percobaan telah membuktikan bahwa citra yang digunakan dapat tersignature dengan baik. 


\section{KESIMPULAN}

Digital signature menjadi penting dalam mengamankan data khususnya citra digital. Beberapa algroitma telah digunakan dalam implementasi digital signature yaitu konvesional Rivest Shamir Adleman (RSA) serta RSA dengan kombninasi fungsi hash. Dalam makalah ini, kami ingin berkontribusi untuk mengimplementasikan digital signature dengan kombinasi RSA-Vigenere cipher dimana citra inputan yang digunakan akan di olah terlebih dahulu dengan MD5. Citra hasil hash dengan MD5 kemudian di olah dengan RSA telebih dahulu baru disubstitusi dengan Vigenere Cipher. Dimana pada penelitian yang dilakukan oleh [11] diimplementasikan dengan melakukan hashing terlebih dahuli pada citra dilanjutkan dengan Vigenere Cipher, hasilnya baru diolah dengan RSA. Perbedaan pada penelitian sebelumnya yaitu kami mengimplementasikan digital signature pada format file yang lebih beragam dan tahaoan operasi algoritma berbeda. Pada makalah ini, hasil implementasi menunjukkan bahwa citra dapat terotentikasi dengan baik. Hal ini dapat diterapkan lebih lanjut untuk mengamankan data pada jaringan misalnya pada email.

\section{DAFTAR PUSTAKA}

[1] D. R. I. M. Setiadi, E. H. Rachmawanto, and C. Sari, "Secure Image Steganography Algorithm Based on DCT with OTP Encryption,” J. Appl. Intell. Syst., vol. 2, no. 1, pp. 1-11, 2017.

[2] M. Najih, D. R. I. M. Setiadi, C. A. Sari, and S. Astuti, "An Improved Secure Image Hiding Technique Using PN-Sequence Based On DCT-OTP," in International Conference on Informatics and Computational Sciences (ICICoS), 2017.

[3] C. Mahalle, M. Kulkarni, T. Nangude, and P. G. Navale, "Digital Signature Authentication and Verification on Smart Phones using CR $\square$ PT Algorithm,” Int. Res. J. Eng. Technol., vol. 4, no. 5, pp. 332-338, 2017.

[4] P. Saha, "A comprehensive study on digital signature for internet security," Accent. Trans. Inf. Secur., vol. 1, no. 1, pp. 1-6, 2016.

[5] G. Ranjith, B. Prathusha, and P. Sagarika, "Arbitrated Digital Signature for e-Authentication Technique of a Digital Message," Int. J. Adv. Eng. Technol., vol. 8, no. 5, pp. 753-761, 2015.

[6] V. Kumar and P. K. Koul, "Robust RSA for Digital Signature," IJCSI Int. J. Comput. Sci. Issues, vol. 8, no. 6, pp. 359-362, 2011.

[7] E. Biham and O. Dunkelman, "A Framework for Iterative Hash Functions-HAIFA.," IACR Cryptol. ePrint Arch., vol. 1, no. August, pp. 1-20, 2007.

[8] K. Ganeshkumar and D. Arivazhagan, "Generating a digital signature based on new cryptographic scheme for user authentication and security," Indian J. Sci. Technol., vol. 7, no. Specialissue6, pp. 1-5, 2014.

[9] D. P. Joseph and M. Krishna, "Cognitive Analytics and Comparison of Symmetric and Asymmetric Cryptography Algorithms,” Int. J. Adv. Res. Comput. Sci., vol. 6, no. 3, pp. 51-56, 2015.

[10] S. Singh, M. S. Iqbal, and A. Jaiswal, "Survey on Techniques Developed using Digital Signature : Public key Cryptography," Int. J. Comput. Appl., vol. 117, no. 16, pp. 1-4, 2015.

[11] R. D. Ardy, O. R. Indriani, C. A. Sari, D. R. Ignatius, and M. Setiadi, "Digital Image Signature using Triple Protection Cryptosystem (RSA, Vigenere, and MD5)," in International Conference on Smart Cities, Automation \& Intelligent Computing Systems, 2017, pp. 1-6.

[12] K. Senthil, K. Prasanthi, and R. Rajaram, "A modern avatar of Julius Ceasar and Vigenere cipher," in 2013 IEEE International Conference on Computational Intelligence and Computing Research, 2013, pp. 1-3.

[13] S. Kromodimoeljo, Teori dan Aplikasi Kriptografi. SPK IT Consulting, 2009.

[14] S. A. Jaju and S. S. Chowhan, "Analytical Study of Modified RSA Algorithms for Digital Signature," Int. J. Recent Innov. Trends Comput. Commun., vol. 3, no. 3, pp. 944-949, 2015.

[15] D. R. I. M. Setiadi, A. E. Handoyo, E. H. Rachmawanto, C. A. Sari, and A. Susanto, "Teknik Penyembunyian dan Enkripsi Pesan pada Citra Digital dengan Kombinasi Metode LSB dan RSA," J. Teknol. dan Sist. Komput., vol. 6, no. 1, p. 37, Feb. 2018. 
Jurnal SIMETRIS, Vol. 10 No. 1 April 2019

P-ISSN: 2252-4983, E-ISSN: 2549-3108

[16] S. Goyal, M. Ramaiya, and D. Dubey, "Improved Detection of 1-2-4 LSB Steganography and RSA Cryptography in Color and Grayscale Images," in 2015 International Conference on Computational Intelligence and Communication Networks (CICN), 2015, pp. 1120-1124. 